\title{
The influence of family firm image on access to financial resources in family SMEs: a signaling theory perspective
}

\author{
Unai Arzubiaga $^{1}\left(\mathbb{D} \cdot\right.$ Alfredo De Massis $^{2,3,4,5} \cdot$ Amaia Maseda $^{1} \cdot$ Txomin Iturralde $^{6}$
}

Received: 15 June 2021 / Accepted: 28 December 2021 / Published online: 13 January 2022

(c) The Author(s) 2022

\begin{abstract}
This study investigates whether a projected family firm image can affect access to financial resources, which is key to providing broader strategic options and meeting short-term financial needs, especially for small and medium-sized enterprises (SMEs). Building on the signaling literature, we consider the family SME leaders' perspective and conceptually and empirically examine whether they believe a projected family firm image acts as a credible signal to the lender. We also examine additional boundary conditions influencing the family SME's projected imageaccess to financial resources relationship, by specifically investigating whether firm age and size alter the degree of the signaling effect. Our unique data on 289 Spanish family SMEs reveal that projected family firm image can act as an attractive signal to lenders, leading to better access to financial resources for SMEs. Furthermore, firm size reinforces the role of the projected family firm image as a positive signal. These findings address an important practical issue in terms of family firm stakeholder perceptions, offering contributions to the corporate branding, family business, and financing literature.
\end{abstract}

Keywords Family SMEs · Family firm image - Access to financial resources · Signaling theory $\cdot$ Firm age $\cdot$ Firm size

JEL Classification M10 $\cdot$ M30 $\cdot$ M31 $\cdot$ L20

\section{Introduction}

Research on corporate branding is gaining momentum and increasingly drawing the attention of management research in the family business context (Beck et al. 2020; Binz-Astrachan et al. 2018; Covin et al. 2016; Rovelli et al. 2021). According to established inference-based conceptualization (Lude and Prügl 2018), a family

Unai Arzubiaga

unai.arzubiaga@ehu.eus

Extended author information available on the last page of the article 
firm's brand is defined as the formal and informal communication of the family nature of a firm (image) that leads to associations and expectations in the minds of stakeholders that help differentiate them from other firms (Sageder et al. 2018; Van Gils et al. 2019). While research indicates that the projection of the family nature of a firm acts as a signal that can potentially influence external stakeholders' perceptions of the firm (Arijs et al. 2018), there is no clear understanding of the manner in which this projection influences their perceptions (Botero et al. 2018). Family business scholars report mixed results on family firm brand perceptions and how stakeholders assess the family nature of a firm, suggesting both positive (e.g., trustworthy) and negative (e.g., old-fashioned) effects (Kallmuenzer et al. 2020; Botero et al. 2018; Schellong et al. 2019). Most studies have been conducted in the consumer context to understand how family firm products or services are perceived by consumers (Botero et al. 2013; Lude and Prügl 2018; Zanon et al. 2019), or in an organizational context, focusing on employee perceptions of family firm identity (Hauswald et al. 2016; Kahlert et al. 2017). However, empirical evidence on the effects of the projected family firm image, understood in terms of how the family firm wants to be perceived by external stakeholders in other fields, is still lacking (Santiago et al. 2019).

Our study aims to fill this research gap by focusing on the effect that a projected family firm image may have with regard to small and medium-sized enterprises' (SMEs) access to financial resources. Proper access to financial resources provides broader strategic options and meets short-term financial needs (Cruz et al. 2021; Michiels and Molly 2017), particularly for SMEs (Lee et al. 2015), which often suffer from resource constraints (Fabrizio et al. 2021). Greater access to financial resources provides firms with more options to choose from to make better strategic investment decisions (George 2005; López-Delgado and Diéguez-Soto 2020) as well as meet short-term financial needs (Schneider and Veugelers 2010). Overall, access to financial resources is considered one of the main challenges faced by family SMEs (European Commission 2015a), pushing these businesses to compete in the market with other companies. To this aim, a strong corporate brand can provide the firm with a competitive advantage through differentiation (Knox and Bickerton 2003). However, despite the family nature of the firm helping to differentiate family businesses from others in a crowded marketplace (Krappe et al. 2011), many family SMEs do not communicate their family nature (Micelotta and Raynard 2011).

Building on the signaling literature, we consider the family SME leaders' perspective to conceptually and empirically examine whether they perceive that the projected family firm image acts as a credible signal to the receiver (i.e., lender). Signaling theory is fundamentally concerned with reducing information asymmetry between two parties (Spence 2002), as this may cause uncertainty regarding the quality of products or services as well as the characteristics and trustworthiness of businesses (Baek et al. 2010). In fact, this uncertainty is associated with higher perceptions of risk, a factor that may hinder the proclivity of external stakeholders, especially lenders, toward less known businesses (Baek et al. 2010). To minimize this uncertainty, firms send signals that contain information about the signaler, so that the projected firm image acts as a signal of non-visible business characteristics and other brand associations (Erdem and Swait 2004; Schellong et al. 2019). This 
is especially relevant in the case of family SMEs, where the overlap of the family and the business systems turns the projected family firm image into a unique, noninimitable resource (Zanon et al. 2019). Nevertheless, no research to date has examined whether the projected family firm image acts as a signal when accessing financial resources. Thus, we aim to address this gap by examining whether a projected family firm image influences the access to financial resources in family SMEs. Furthermore, we examine additional boundary conditions influencing the family SME's projected image-access to financial resources relationship, by specifically investigating whether firm age and size alter the degree of the signaling effect.

We test these effects in a sample of 289 Spanish family SMEs, providing two key contributions to the corporate branding, family business, and financing literature streams. First, we advance the corporate branding and family business literature by situating family firm image within signaling theory, revealing that one's image can provide a credible signal of quality that facilitates access to financial resources (Connelly et al. 2011). This is a relevant theoretical perspective in understanding how the associated perceptions of a firm's family nature may affect the business. Signaling theory related to specific stakeholders, such as lenders, allows further study of family firm branding (Chandler et al. 2019; Craig et al. 2008). Second, we advance financing research on the antecedents and implications of obtaining external funds. We provide a more detailed explanation of how access to financial resources depends on tangible factors as well as intangible ones, such as the image of the business. In our approach, the notion of a projected image determines how family firm leaders interpret access to financial resources according to a self-assessment criterion. We move beyond the current family business branding literature by measuring perceived (rather than successful or failed) access to financial resources, thus including firms that would otherwise be excluded (e.g., discouraged borrowers). This subjective measure enables a more comprehensive understanding of family firm behavior regarding its access to financial resources than would be the case with purely objective data $(\mathrm{McCa}-$ rthy et al. 2017). Moreover, we respond to Crespí and Martin-Oliver's (2015) assertion that much work remains to be done on the variables that affect the perceptions of family SMEs in relation to access to financial resources.

\section{Theoretical background and hypotheses development}

This study builds on signaling theory (Spence 1973), specifically in the family firm and financial context. In our theoretical development, we focus on whether the family nature of a firm might induce reliability perceptions and be perceived as financially stable (Schellong et al. 2019) by external stakeholders in general, and lenders in particular. In the following sections, we outline the main theoretical foundations of the corporate branding concept, differentiating between corporate identity, image, and reputation and develop our hypotheses centered on the projected image of a family firm. 


\subsection{Corporate branding and firm image}

Corporate branding is a holistic brand management approach that firms adopt to build a distinctive corporate identity (Abratt and Kleyn 2012). In this vein, Eggers et al. (2013) state that in recent years, scholars have become increasingly interested in the phenomenon of corporate branding. Beck et al. (2020; p. 95) affirm that this is because a strong brand "enhances consumer value creation (Anker et al. 2015), enhances customers' brand loyalty (Chaudhuri and Holbrook 2001), helps distinguish them from competitors (Aaker 2004; Kastanakis and Balabanis, 2012), positively influences new product evaluations (Besharat 2010), and thus increases company performance through brand equity (LaPlaca 2010)." Corporate brand becomes the face of the organization (Balmer and Gray 2003). It comprises both the mechanisms employed by the firm to project its corporate identity to external stakeholders and how this identity is perceived by them (Abratt and Kleyn 2012). Thus, interrelated concepts arise, such as corporate identity, corporate image, and corporate reputation. Corporate identity is a strategic element strongly linked to a corporation's mission, vision, value, and culture. However, corporate image is a managerial concept to create a corporate brand, which comprises both projecting an image to outside the business and understanding how external stakeholders make decisions in relation to the firm, its products, and services (da Camara 2011). The external perception of the organization, which only exists in the eyes of key stakeholders, is referred to as corporate reputation (Gotsi and Wilson 2001; Van Gils et al. 2019).

Concerning the concept of image, there is a terminological confusion in the literature. As Foreman et al. (2012) note, this concept is generally framed in three primary ways: (1) projected or intended image, (2) perceived or intercepted image, and (3) reflected or constructed image (for some extensive reviews, see Brown et al. 2006). Scholars conceptualizing the image as a projection focus on messages sent from the firm to external stakeholders on how the former wants to be viewed externally, such that the projected image is closely related to the corporate identity. This is also referred to as projected, planned, intended, and desired (external) image, or desired projected identity. Other scholars refer to the notion of the image as a perception based on the impressions that external stakeholders have of the organization, which are known to the firm to the extent that they are publicly expressed by the stakeholders (Kallmuenzer et al. 2020). This perceived or intercepted image is related to corporate image. Scholars have also conceptualized the image as a mirror reflection of external stakeholders' perceptions of the firm, using the terms reflected, construed, refracted, and interpreted image. Several marketing scholars consider this notion analogous to reputation (Brown et al. 2006; Gotsi and Wilson 2001).

In short, the different framings of image rest on interaction and feedback between the top management team (TMT) and the external audience. In other words, the TMT develops a projected image of how it wants the firm to be perceived by external stakeholders whereas the firm's perceived image relies on how the external audience receives the intended image. Given the difficulty in obtaining information about stakeholder perceptions, some scholars suggest that it is more accurate to use the term construed image, implying what managers believe external stakeholders think of the firm (Brown et al. 2006). 
In the present study, we employ the term projected family firm image, including the different components that capture the firm's efforts to achieve its desired corporate brand identity through the visual, verbal, and behavioral expressions of its unique family nature.

\subsection{Projected family firm image as a signal}

There is consensus that the corporate brand fosters the image perceived by stakeholders and their overall impression of the firm (Abratt and Kleyn 2012; Hatch and Schultz 2003), and that a strong corporate brand can provide the firm with a competitive advantage through differentiation, generating brand preference and loyalty in the minds of multiple stakeholders (Balmer and Gray 2003; Hatch and Schultz 2003; Knox and Bickerton 2003). In the family firm context, the family nature of a firm differentiates it from others in a crowded marketplace (Craig et al. 2008; Garcés-Ayerbe et al. 2021), acting as a signal that can influence external stakeholders' perceptions (Arijs et al. 2018; Binz-Astrachan et al. 2018). The question then arises as to whether the family firms' character is positively perceived. As Lude and Prügl (2018) indicate, although an increasing number of family firms explicitly advertise that they are a "family business," many others do not communicate this (Micelotta and Raynard 2011).

Drawing on signaling theory (Spence 1973, 2002), our central assumption is that the family nature of the firm (i.e., projected image of a family firm) is a credible signal to lenders. Signaling theory is widely used in different literature streams (Taj 2016), and particularly in the marketing field in recent years (Connelly et al. 2011). Scholars have increased the range of potential signals and contexts in which signaling may explain consumer perceptions (Pappu and Quester 2016). Information asymmetry (i.e., one side knows more than the other) may cause uncertainty regarding the quality of products or services, their characteristics, and qualifications (Baek et al. 2010). Thus, this uncertainty is associated with higher perceptions of risk, a factor that may hinder the proclivity of consumers toward products or services that are less known (Baek et al. 2010). To decrease or avoid this uncertainty, firms send signals that contain information about the signaler, so that the projected firm image acts as a signal of non-visible product quality and other brand associations (Erdem and Swait 2004; Schellong et al. 2019).

In the case of family businesses, the overlap of the family and business systems provide a unique identity by which they can build a distinctive brand (Brinkerink et al. 2020). Family firm image is regarded as an inimitable resource, comprising the family's unique history, the family and firm's values, and the identity embodied by family members over time (Blombäck 2011; Binz-Astrachan et al. 2018; Zanon et al. 2019). On the one hand, family firms are perceived as trustworthy and authentic (Beck and Kenning 2015; Carrigan and Buckley 2008; Lude and Prügl 2018; Orth and Green 2009), customer-oriented and quality-driven (Cooper et al. 2005; Sundaramurthy and Kreiner 2008), benevolent (Beck and Prügl 2018), and socially responsible (Schellong et al. 2019). This indicates that communicating the family business nature is likely to result in higher perceptions of family firm image (Binz-Astrachan 
et al. 2013; Deephouse and Jaskiewicz 2013; Sageder et al. 2018). On the other hand, the family nature of a firm can lead to negative perceptions among stakeholders such as appearing limiting, old-fashioned, or less innovative (Casado-Belmonte et al. 2021; de Groote et al. 2021; Krappe et al. 2011), which may hinder consumers' proclivity toward the firm's products and services, resulting in a decrease in sales (Sageder et al. 2018).

The empirical evidence presented above has been largely conducted in the consumer context, focusing on consumer perceptions of family firms in terms of trust and buying intention (Arijs et al. 2018). Unfortunately, there is scant empirical evidence on the reputational effects of communicating the family nature of the firm to other stakeholders with "legitimate interests in procedural and/or substantive aspects of the corporate activity" (Donaldson and Preston 1995, p. 85). Specifically, this study focuses on an important stakeholder group, namely lenders, because access to financial resources is of great relevance for the sustainability, growth, innovation, and entrepreneurship of firms (Blanco-Mazagatos et al. 2007; Oliveira and Fortunato 2006; Molly et al. 2012; Kerr and Nanda 2015). This analysis could explain the signals received in terms of access to financial resources by family businesses that communicate their family firm characteristics.

\subsection{The effect of projected family firm image on access to financial resources}

While financial capital is a key resource for any firm, this is especially important in SMEs that often suffer from resource constraints. Greater access to financial resources provides firms with broader options that allow them to make better strategic investment decisions (George 2005), face liquidity problems (Lee et al. 2015), and meet short-term financial needs (Schneider and Veugelers 2010). Moreover, resource constraints in other areas can, to some extent, be mitigated by access to financial resources (Wiklund and Shepherd 2005).

Access to financial resources is one of the main challenges that family firms face (European Commission 2015a), depending not only on the borrower but also on the lender's perceptions of risk of default and uncertainty. According to Stiglitz (2000), uncertainty is attributable to two broad types of information asymmetries: information about quality (when one party is unaware of the characteristics of the other party) and information about intent (when one party is concerned about the behavior or behavioral intentions of the other party), which might hinder firms from accessing financial resources. In this regard, the role of signaling in understanding how the two parties, that is, the borrower (the family firm) and the lender (the financial entity), resolve information asymmetries is pivotal (Connelly et al. 2011) and may influence how family firm leaders perceive their access to financial resources.

Given that family firms are characterized as having longer planning horizons to transfer the business to future generations (Miller and Le Breton-Miller 2006; Zellweger 2007), their leaders seek to transfer their legacy to their descendants and provide a sustainable income stream for subsequent generations (Dyer and Whetten 2006; Zellweger et al. 2012). Long-term orientation is considered a distinct core value of family firms (Sirmon and Hitt 2003; Strobl et al. 2020), guiding 
organizational behavior and decision-making (Bichler et al. 2021; Nag et al. 2007). Zellweger et al. (2012, p. 244) argue that "in working to create a long lasting successful firm, family firm leaders often build companies that are resistant to faddish trends (Craig et al. 2008), instead choosing to promote the longstanding nature of the family firm with continuous family involvement and steadfast investment strategies". The same authors add that the long-term orientation of family firms helps send the message that they are here for the long haul and are determined to behave responsibly in relation to long-term sustainability. Communicating the family firm identity can be a signal of trustworthiness that encompasses their unique behavioral characteristics, sending information about quality (fostering the lender's awareness of the characteristics of the family firm) and intent (helping reduce the lender's concern about the behavioral intentions of the family firm). In other words, communicating the family nature of the firm through the projected family firm image evokes the characteristics of certainty, long-term sustainability, and low risk inherent in these firms.

Considering the above, we assume that the projected family firm image is positively associated with access to funds available through external borrowing. Thus, we propose:

Hypothesis 1: The projected family firm image positively influences the access to financial resources.

Following Sageder et al. (2018) and focusing on specific features relevant to creating and developing the family firm image, we analyze the moderating effect of two sources of diversity (i.e., firm size and firm age) on the relationship between the projected family firm image and access to financial resources. Specifically, we propose that firm age and size are key contingency factors that render the family firm image a more salient signal and will thus have a greater effect on access to financial resources.

\subsection{The moderating effect of family firm age and size}

Family firm age, measured as the number of years since the firm was established (George 2005), is likely to influence the relationship between projected family firm image and access to financial resources. Based on signaling theory considerations, it is reasonable to assume that firms that remunerate their sources of financing over the long-term signal credibility to lenders in terms of the quality of the firm (Connelly et al. 2011). This mitigates uncertainty for lenders (Crespí and Martin-Oliver 2015; Vos et al. 2007), ensuring continuous cash inflows from financial liabilities (Kashmiri and Mahajan 2010). Moreover, the projected family firm image often evokes the perception that family firms are more trustworthy (Beck and Kenning 2015; Beck and Prügl 2018; Carrigan and Buckley 2008), which is built by family firms' leaders and members over the years.

In addition, family firm leaders are especially concerned with ensuring the longevity of the business and creating the necessary conditions for its future sustainability. 
Communicating the family nature of the firm promotes the notion of its longevity. It avoids putting the family's own wealth at risk by ensuring the low volatility of the firm's cash flows (Steijvers and Voordeckers 2009). This may help lenders ascertain that their interests are in line with those of the family, thereby providing better financing conditions (Chua et al. 2009; Crespí and Martin-Oliver 2015). In this regard, the projected family firm image becomes more solid and meaningful as time passes, resulting in a more effective and powerful signal when accessing financial resources. Thus, older firms may have an advantage in terms of maximizing the positive effect of the projected family firm image when accessing financial resources via debt.

Considering the above, we assume that the positive effect of the projected family firm image on access to financial resources is stronger in older than in younger family SMEs. Thus, we propose:

Hypothesis 2: The positive effect of the projected family firm image on access to financial resources is stronger for older than for younger family SMEs.

Firm size, measured as the number of employees (Lu and Beamish 2001), is likely to influence the projected family firm image-access to financial resources relationship. On the one hand, larger family firms usually have more resources available to develop the firm's image-related initiatives, which may result in a more effective signal to lenders about the family status of these firms (Botero 2014). On the other hand, larger family firms usually have a better growth and performance history, which could further strengthen the projected family firm image as a credible signal evoking a long-term vision and a trajectory of success. Relatedly, larger family firms are usually regarded as less resistant to change and more competitive than smaller firms (Krappe et al. 2011), which may reduce lenders' concerns of nepotism and hiring less qualified professionals. All these factors confer more stable and prestigious considerations to larger family firms compared to their smaller counterparts (Memili et al. 2010), which are crucial when accessing external financial resources (Sageder et al. 2018). Thus, larger firms may have an advantage in terms of maximizing the positive effect of projecting the family firm image when accessing financial resources through debt (Fig. 1).

For all these, we assume that the positive effect of projected family firm image on access to financial resources is stronger in larger than in smaller family SMEs. Thus, we propose:

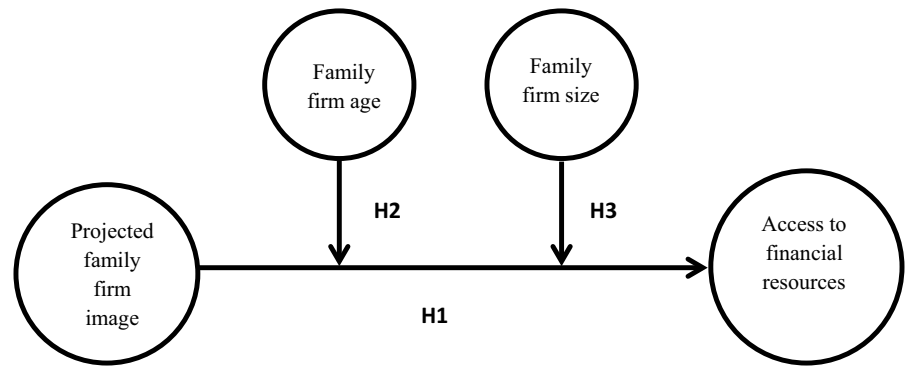

Fig. 1 Research model and hypotheses 
Hypothesis 3 The positive effect of projected family firm image on access to financial resources is stronger for larger than for smaller family SMEs.

\section{Methodology}

\subsection{Sample and data collection}

We tested our hypotheses quantitatively using a survey and secondary data from Spanish family SMEs. Focusing on family firms in a European country such as Spain is very noteworthy, as Spain features a predominance of family-controlled firms (Alayo et al. 2019) and family SMEs (Fernández-Olmos et al. 2016). As in other European countries, 90\% of Spain's active businesses in 2015 were family businesses according to the Spanish Family Business Institute (Casillas et al. 2016). Moreover, these types of firms make a considerable contribution to the Spanish economy, accounting for more than $60 \%$ of the gross domestic product and around $70 \%$ of employment in the private sector (Casillas et al. 2016). A study published by the European Commission (2015b) indicates that in line with countries such as Austria, Cyprus, Greece, Italy, the Netherlands, and Portugal, Spain is below the EU average regarding the availability of different financing sources for SMEs. This emphasizes the suitability of this country as the research setting for the study.

The survey was based on established measures in the literature and used to obtain information that would be unavailable or difficult to acquire for non-listed firms. Secondary data were obtained from the Iberian Balance Sheet Analysis System (SABI) database. The survey data were collected in June 2013 through telephone interviews conducted by a professional survey firm to ensure quality and a high response rate. Prior to this, we had sent a letter presenting our research to the CEOs of these firms, requesting their collaboration. We selected CEOs as our respondents as they are considered the most qualified to provide information on organizationlevel issues (Memili et al. 2010).

The questionnaires for the secondary data were addressed to Spanish family SMEs in the SABI database. Although there are different criteria for identifying family firms (Roffia et al. 2021; Westhead and Cowling 1998), we chose the following two based on prior research (Arosa et al. 2010; Dyer 2003; Voordeckers et al. 2007): (1) ownership structure- namely, whether one or more families control the business ownership, with $50 \%$ as the minimum equity required for a family to have control of a firm; and (2) active participation in the firm's management. Based on these criteria and using the data available in the SABI database, a detailed examination of the shareholding structure (percentage of common stock) and the identity of owners and TMT members was conducted, focusing on their names and surnames. Indeed, the Spanish surname system allows identification of family relationships, including second-degree relationships (e.g., uncles, aunts, first cousins) based on surnames, since children take both their father's and mother's surnames. Additionally, the family firm status was checked using the respondents' self-identification of their business as a family firm (Arzubiaga et al. 2018). 
We then refined the sample by removing entries without mailing addresses and those with incongruent data. In addition, given that the data collection is part of a larger study, we followed Roffia et al. (2021) to operationally define family SMEs by restricting our sample to family businesses with between 11 and 250 employees (i.e., family SMEs) and a board of directors (albeit not a relevant criterion for this study). The final sample contained 1,710 family SMEs. We pre-tested the questionnaire to ensure that the questions were clear and easily understood by conducting informal interviews with nine randomly chosen family firm CEOs who were not included in the sample and were engaged to discuss the survey instrument and adapt the wording where necessary.

Starting with a sample of 1,710 non-listed Spanish SMEs, we obtained 289 responses $(13.45 \%$ ), a typical response rate for this type of research (Wiklund and Shepherd 2005). We tested for any non-response bias by comparing early and late respondents (Michiels et al. 2021). We divided the total pool into two response waves based on the order in which the responses were received. However, we found no statistically significant difference, suggesting that non-response bias is not a problem in our study (Armstrong and Overton 1977). Moreover, the non-response analysis revealed no statistically significant differences between respondents and non-respondents regarding age, debt, and size $(p>0.1)$.

\subsection{Common method bias}

Given that this study relies on CEOs as key respondents and on information provided by one person in a single timeframe (Campbell and Fiske 1959), we controlled for common method bias. To reduce the potential common method variance, we implemented ex-ante adjustments in the survey design. First, to avoid the problem of key participants responding in a socially desirable manner, we ensured anonymity and absolute confidentiality (Podsakoff et al. 2003). Second, the independent and dependent variables were divided among different sections of the survey to make linking the various concepts more difficult (Kortmann 2015). This design adjustment, in combination with the extensive survey, required respondents to think carefully about each answer. Furthermore, respondents could ask the interviewer to read the instructions and definitions for each question (Podsakoff et al. 2003). Third, different response formats were considered within and across the survey sections following different indices such as "completely agree/completely disagree" and "completely wrong/completely right" (Grewal et al. 2010). In this sense, the dependent and independent variables were based on constructs, with all items measured using 11-point Likert-type scales (Kortmann 2015). Specifically, instead of using the more typical one to five and one to seven scales, zero to ten scales were used given that these are most used in Spain in both academic and non-academic fields (Arzubiaga et al. 2018). However, Dawes (2008) concludes that there is very little difference among the scale formats in terms of variation in the mean, skewness, or kurtosis.

Furthermore, we tested for common method variance by performing two posthoc tests. First, we estimated common method bias using Harman's single-factor test (Harman 1967). This test presumes that if common method bias exists, either a 
single factor will emerge from the factor analysis of all measurement items, or one general factor accounting for most of the variance will emerge (Kortmann 2015). In this case, Harman's single-factor test revealed that the first factor accounted for only $28.1 \%$ of the total variance in the sample, while four factors with eigenvalues greater than 1 accounted for $65.2 \%$ of the variance. Second, we estimated common method bias based on Podsakoff et al. (2003). We included a common method factor (chemical industry) linked to all single-indicator constructs converted from the observed indicators. We compared the indicator variances explained by the method factor with the variances explained by the substantive constructs. On average, the constructs explain $60.67 \%$ of the variance in the sample, whereas on average, the method factor explains $0.49 \%$ of the variance, resulting in a ratio of substantive variance to method variance of about 123.82 (see Table 1). Moreover, most of the method factor loadings were statistically nonsignificant. Given that both tests (i.e., Harman's single factor test and the inclusion of a method factor) indicate a lack of common method bias, we concluded that bias is either absent or negligible (Kortmann 2015).

\subsection{Measures}

While this study employs different variables, only the independent variable (projected family firm image) is based on a multi-item construct, which relies on a previously established scale measured using Likert-type scales.

\subsubsection{Projected family firm image}

The scale chosen to measure projected family firm image was created by Memili et al. (2010) to assess the degree to which an organization attempts to create the firm's projected corporate image as a family firm. Respondents were asked to evaluate the following five items on an 11-point scale $(0=$ "do not agree" to $10=$ "completely agree"): (1) the family firm name is recognized in the community; (2) the family name is used as a brand; (3) advertisements state that the firm is a family business; (4) most customers know that we are a family business; and (5) being a

Table 1 Common method bias

\begin{tabular}{|c|c|c|c|c|c|}
\hline \multirow[t]{2}{*}{ Construct } & \multirow[t]{2}{*}{ Item } & \multicolumn{2}{|c|}{ Substantive factor } & \multicolumn{2}{|c|}{ Common method factor } \\
\hline & & Loading R1 & ${\text { Loading } \mathrm{R} 1^{2}}^{2}$ & Loading R2 & Loading R2 $^{2}$ \\
\hline \multirow{5}{*}{$\begin{array}{l}\text { Projected family } \\
\text { firm image }\end{array}$} & FFI1 & 0.75 & 0.5625 & -0.10 & 0.0104 \\
\hline & FFI2 & 0.69 & 0.4761 & -0.12 & 0.0118 \\
\hline & FFI3 & 0.73 & 0.5329 & -0.05 & 0.0001 \\
\hline & FFI4 & 0.85 & 0.7225 & -0.06 & 0.0025 \\
\hline & FFI5 & 0.86 & 0.7396 & -0.00 & 0.0001 \\
\hline \multirow[t]{2}{*}{ Average } & & & 0.6067 & & 0.0049 \\
\hline & & Ratio & & & 123.82 \\
\hline
\end{tabular}


family business is a useful marketing tool. As is common with multi-item scales in this field, the combined mean of the scale measures constitutes the variable score. Higher overall scores on the five-item scale indicate a greater attempt to create a family firm image, and vice versa.

\subsubsection{Access to financial resources}

We measured access to financial resources using a single-item scale based on the work of Wiklund and Shepherd (2005). The single survey item was "Our access to financial resources is fully satisfactory for the firm's development." We asked respondents to evaluate this item on an 11-point scale $(0=$ "do not agree" to $10=$ "completely agree"). Higher scores indicate a better perception of easy access to financial resources.

We examined the robustness of our results for different firm characteristics by estimating structural models for several subsamples (Gruber et al. 2010). For example, we divided our sample in terms of the generation in control of the business (first, second, or third, and subsequent) and family involvement in the TMT (less than $50 \%$ of family members in the TMT vs. more than 50\%). These analyses produced only minimal differences in the path coefficients for the various sub-models (results are available from the authors).

\subsubsection{Firm age, firm size}

We measured firm age as the number of years since the firm's self-reported establishment (George 2005), and firm size as the current number of full-time employees (Lu and Beamish 2001). We log-transformed both variables to normalize their distribution and standardized them prior to their inclusion in the research model.

\subsubsection{Control variables}

We included different additional variables to ensure proper model specification and to consider possible alternative explanations for our results. As we measured perception, we included control variables that might affect the perceptions of those in charge of the firm. First, we controlled for whether the CEO was a family member using a dummy variable ( 1 if the CEO was a family member, and 0 otherwise). Second, we controlled for the proportion of family members in the TMT. Third, we controlled for industry (chemical, energy, food, furniture, textile, and steel, the last omitted). Finally, we controlled for the generation in control, as the generation running the business may affect financing (Neckebrouck et al. 2021).

\subsection{Analytical techniques}

Structural equation modelling (SEM) was used to test the proposed relationships. One of the main advantages of SEM is that it allows for testing a model in a full information setting rather than piecemeal using regression techniques (Robeson and 
O'Connor 2013). In addition, compared with a regression analysis, SEM is more appropriate for examining theoretical models with latent compound constructs (Hair et al. 2012). Performing a linear regression analysis on the data requires a simplification of the content of each construct, suggesting that some information might be lost when creating an index for each construct or variable (Gefen et al. 2000). In this sense, a regression analysis is appropriate when analyzing directly measurable variables but is somewhat limiting for latent constructs (Azim 2012). Specifically, we used the partial least squares (PLS) approach whose features have led to its increased use in management, strategy, marketing (Landau and Bock 2013), and family business research (Binz-Astrachan et al. 2014). First, the partial least squares structural equation modeling (PLS-SEM) method is preferred when analyzing predictive research models in the early stages of theoretical development (Elbanna et al. 2013). Second, the PLS approach can capture the normative implications of the total system of variables and holistically clarify the overall model (Schuster and Holtbrügge 2014). This was relevant in our case because we estimated a model of simultaneous relationships aiming to provide a complete overview of the impact of the projected family firm image on access to financial resources. Third, the PLS-SEM algorithm transforms non-normal data using the central limit theorem (Hair et al. 2012), making the PLS-SEM results robust when using skewed data.

We used SmartPLS 3 to estimate the model and tested the significance of the PLS estimates using the bootstrap method (Hair et al. 2012; Ringle et al. 2005). According to Thai and Turkina (2014), the bootstrap procedure in SmartPLS 3 enables the calculation of standard deviations and approximations of $t$-statistics, overcoming the lack of formal significance tests for the estimated parameters in nonparametric methods (Chin 1998). To estimate whether the relationships in our model are statistically significant, we constructed bootstrap percentile confidence intervals (Berghman et al. 2013). We used 5,000 bootstrap samples each containing the same number of observations as the original sample. Furthermore, we allowed for individual sign changes in the bootstrap procedure (Hair et al. 2012).

\section{Results}

\subsection{Descriptive analysis}

Table 2 summarizes the main descriptive statistics of the participating firms. The multi-industry sample includes firms with an average 95.89 employees, operating for an average 31.31 years. In terms of control, $24.91 \%$ of the firms are controlled by the first generation, $41.87 \%$ by the second generation, and $33.22 \%$ by the third and subsequent generations. With respect to the CEO, $49 \%$ of the firms are controlled by family CEOs and $51 \%$ by non-family CEOs. 
Table 2 Sample description

\begin{tabular}{|c|c|c|c|}
\hline Firm characteristics & & $\mathrm{N}=289$ & $\%$ \\
\hline \multirow[t]{5}{*}{ Firm size (employees) } & 11-50 employees & 21 & 7.27 \\
\hline & 51-100 employees & 163 & 56.40 \\
\hline & 101-150 employees & 67 & 23.19 \\
\hline & 151-200 employees & 29 & 10.03 \\
\hline & 201-250 employees & 9 & 3.11 \\
\hline \multirow[t]{5}{*}{ Firm age (years) } & More than 40 years & 57 & 19.73 \\
\hline & 31 and 40 years & 60 & 20.76 \\
\hline & 21 and 30 years & 101 & 34.94 \\
\hline & 11 and 20 years & 61 & 21.11 \\
\hline & Less than 10 years & 10 & 3.46 \\
\hline \multirow[t]{2}{*}{ CEO (family/non-family) } & Family member CEO & 142 & 49.13 \\
\hline & Non-family member CEO & 147 & 50.87 \\
\hline \multirow[t]{4}{*}{ Family TMT ratio (senior managers) } & Less than $25 \%$ & 93 & 32.17 \\
\hline & $26-50 \%$ & 84 & 29.06 \\
\hline & $51-75 \%$ & 33 & 11.43 \\
\hline & $76-100 \%$ & 79 & 27.34 \\
\hline \multirow[t]{3}{*}{ Generation in control } & First generation & 71 & 24.91 \\
\hline & Second generation & 122 & 41.87 \\
\hline & Third and subsequent generations & 96 & 33.22 \\
\hline \multirow[t]{6}{*}{ Industry } & Chemical & 57 & 19.72 \\
\hline & Energy & 18 & 6.23 \\
\hline & Food & 73 & 25.26 \\
\hline & Furniture & 29 & 10.04 \\
\hline & Textile & 8 & 2.77 \\
\hline & Steel & 104 & 35.98 \\
\hline
\end{tabular}

\subsection{Measurement model}

We analyzed the psychometric properties of our single latent construct, projected family firm image. Here, we measured the construct based on: (1) individual item reliability, (2) the convergent validity of the measure associated with individual constructs, and (3) discriminant validity (Hulland 1999). Item reliability relates to the degree to which an item loads on its intended construct. Given that the shared variance between an item and a construct should be higher than that between the construct and error variance, the items should have loadings higher than 0.7 (Hulland 1999). All items in the measurement model satisfy this condition (item $1=0.75$; item $3=0.73$; item $4=0.85$; item $5=0.86)$ except for item $2(0.69)$, which we decided to retain because of its statistical significance $(t=15.40)$. Next, we examined convergent validity using composite reliability (CR) and Cronbach's alpha, applying the suggested 0.7 benchmark for reliability (Hulland 1999). The family firm image measure exceeded this benchmark (Cronbach's alpha $=0.84$; composite 


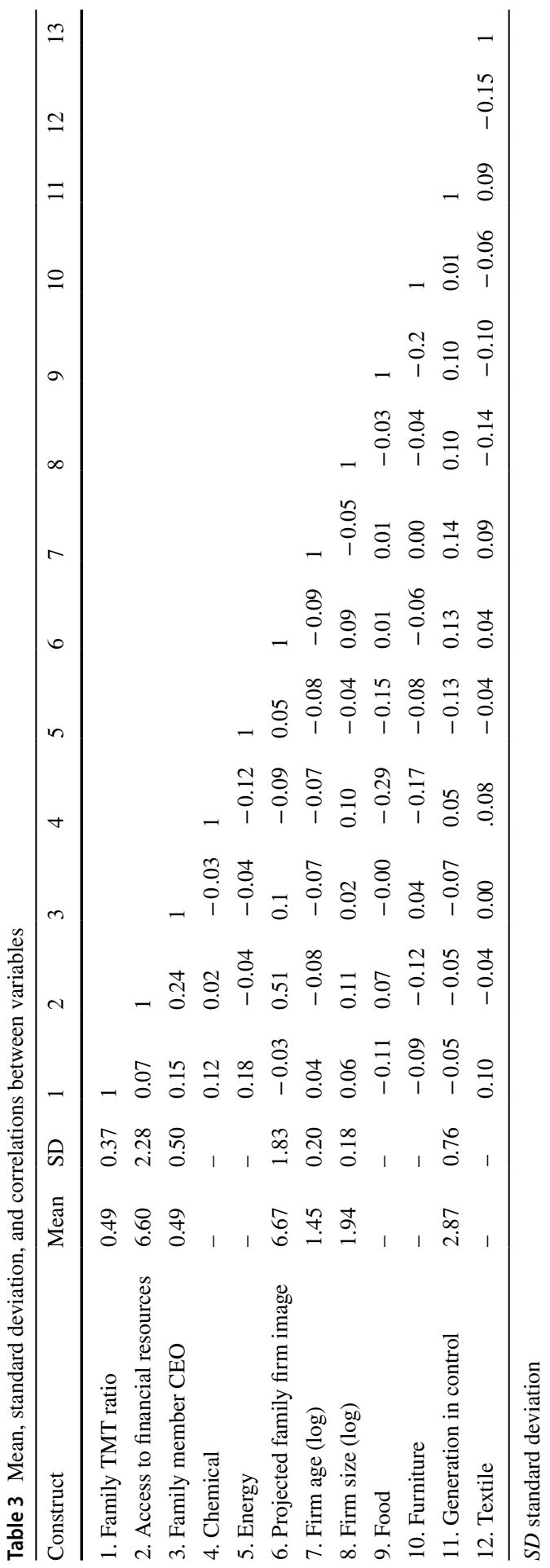


reliability $=0.88$ ), indicating internal consistency. Furthermore, we analyzed the discriminant validity of the measures according to whether the average variance extracted (AVE) of a measure was greater than 0.5, and whether its square root was greater than its coefficients of correlation with the other measures (Chin 1998). The scale met these criteria (AVE $=0.61$ ). Given that Hulland's (1999) proposed requirements were all fulfilled, the psychometric properties showed adequate reliability and validity. Table 3 reports the mean and standard deviation of the variables, as well as their correlations.

\subsection{Structural model}

We tested the quality of the structural model assessment by estimating the path coefficients, their significance using bootstrap tests, their $\mathrm{R}^{2}$ values, and the Stone-GeisserCriterion $\left(\mathrm{Q}^{2}\right)$, which we derived using the blindfolding procedure with an omission distance of 7 for predictive relevance (Tenenhaus et al. 2005). Our dependent variable indicates $\mathrm{R}^{2}$ values above 0.1 (Falk and Miller 1992) for the structural models. Furthermore, the cross-validated redundancy indices $\left(\mathrm{Q}^{2}\right)$ confirm that the structural models have satisfactory predictive relevance for the endogenous variable (i.e., access to financial resources).

To test the direct effect of the projected family firm image (H1) and the moderation hypotheses of firm age $(\mathrm{H} 2)$ and firm size $(\mathrm{H} 3)$, we estimated the significance of these relationships in our model using the bootstrapping technique (Hair et al. 2012). Specifically, we assessed the signs and magnitudes of the path coefficients and their $t$-values, which we obtained by applying nonparametric bootstrapping, and calculated the effect sizes and total effects (Chin 1998). These results were grounded within the decision spectrum offered by Mai et al. (2021), who found that three critical distinctions regarding model novelty, focus on structural model, and sample size are crucial to exploit the particular strengths of fit indicators. Accordingly, we followed this suggested strategy in order to select the recommended indicators that may avoid different potential statistical inaccuracies.

The direct effect of the projected family firm image on access to financial resources was positive and significant $\left(\beta=0.507 ; t=9.31 ; \mathrm{R}^{2}=0.332\right)$, supporting H1. For $\mathrm{H} 2$ and $\mathrm{H} 3$, we considered the contingency effects of firm age and firm size on the projected family firm image-access to financial resources relationship. The results indicate that the effect of projected family firm image on access to financial resources increases with firm size $\left(\beta=0.193 ; t=2.68 ; \mathrm{R}^{2}=0.370\right)$ but does not vary with firm age $\left(\beta=-0.118, t=1.62: \mathrm{R}^{2}=0.339\right)$. Hence, the results did not support $\mathrm{H} 2$ but supported $\mathrm{H} 3$. Finally, with regard to the control variables, only the fact of being a family member CEO $(\beta=0.24, \mathrm{t}=6.17 ; p<0.001)$ had a positive influence on the access to financial resources, while the proportion of family members in the TMT, the industry and the effect of the generation in control were not found to be statistically significant (Fig. 2). 


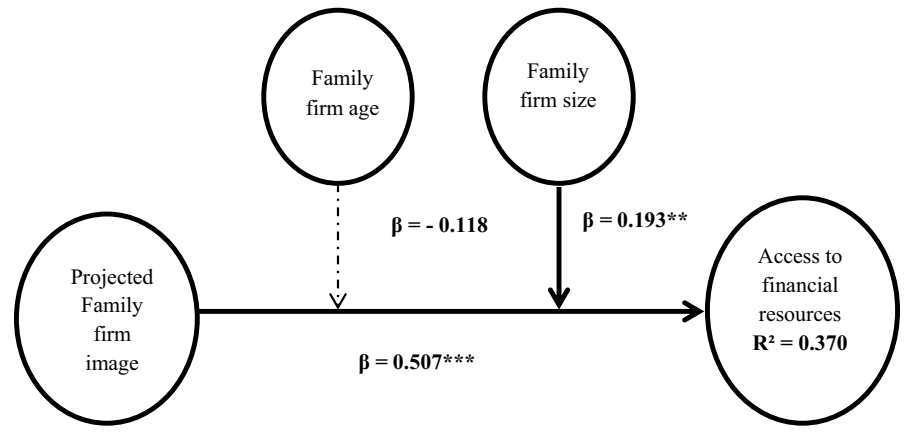

Fig. 2 Research model test $(\mathrm{n}=289)$. Statistical significance: $* * * p<0.001 ; * * p<0.01$

\section{Discussion}

\subsection{Findings and theoretical contributions}

Family firm image has received growing research attention in recent years (Beck et al. 2020; Botero et al. 2018; Kallmuenzer et al. 2020; Van Gils et al. 2019). Most of this research has focused on how the family firm image influences, on the one hand, consumers' proclivity toward family firms' products and services (Lude and Prügl 2018; Zanon et al. 2019), and on the other hand, how employees perceive family firms (Kahlert et al. 2017). Nevertheless, the impact of family firm image on other stakeholders' perceptions has been largely overlooked (Santiago et al. 2019). Thus, this study focused on lenders as a particular stakeholder group, building on signaling theory (Spence 1973) to analyze the impact of projected family firm image on how family firm leaders perceive their firm's access to financial resources. Prior research proposes that financial institutions place greater trust in business owner characteristics than in other business characteristics when evaluating commercial lending outcomes (Vos et al. 2007). In this regard, family SME scholars are divided on whether the family nature of a firm enhances or hinders access to financial resources (Kärreman and Rylander 2008; Steijvers and Voordeckers 2009). As such, our study responds to this important issue and goes one step further by studying the contingent effects of firm age and firm size on this relationship.

Based on signaling theory, our findings support the general logic of our argument, showing that a projected family firm image can act as an attractive signal to lenders, leading to better access to financial resources from the perspective of family firm leaders. In addition, this finding allows us to provide a more detailed insight into how access to financial resources depends on certain intangible factors, such as family firm image. In this vein, this finding may reinforce the idea that projecting the family nature of the firm may be of great help to differentiate family businesses from others in a crowded marketplace (Krappe et al. 2011) since the projected family firm image may evoke an image of trustworthiness (Beck and Kenning 2015), socially-responsible (Schellong et al. 2019) and customer-oriented and quality-driven (Sundaramurthy and Kreiner 2008). Such a 
perception could help family SMEs compete with their counterparts when accessing to financial resources in a context with low availability of different financing sources for SMEs. Likewise, this insight may also push the family SMEs that do not communicate their family nature (Micelotta and Raynard 2011) to project their family firm image.

Conversely, we confirmed our hypothesis that the positive effect of projected family firm image on access to financial resources is moderated by the size of the family SME (H3). This finding reinforces our rationale that, compared to smaller firms, medium-sized family firms can take advantage of two factors to develop more effective projected family firm image signaling to lenders. First, they can use additional resources to develop more image-related initiatives. Second, they can communicate their experience and performance history, which could reinforce the projected family firm image as a signal, evoking a long-term vision and a sustainable trajectory. Regarding the moderating effect of firm age $(\mathrm{H} 2)$, and contrary to our expectations, our findings do not support the hypothesis that older family SMEs can leverage this advantage in accessing to financial resources. The age of the firm affects how family firms finance their activities (Romano et al. 2001) and build a reputation (Sageder et al. 2018), but we cannot assert that firm age moderates the projected family firm image-access to financial resources relationship. Regarding the control variables, our results offer an interesting insight because the CEO being a family member positively influences access to financial resources. This may be related to the pride that family CEOs may have and their feeling that the projected image of their family firm is equally appreciated by external stakeholders such as lenders.

This study contributes to our understanding of the effect of projected family firm image on access to financial resources in several ways. First, this study extends current corporate branding and family business literatures by situating family firm image within signaling theory, revealing that image can provide a credible signal of quality that facilitates access to financial resources (Connelly et al. 2011). This meaningful theoretical perspective shows how the associated perceptions of a firm's family nature may influence the business. Likewise, signaling theory related to specific stakeholders, such as lenders, allows further study of family firm branding (Chandler et al. 2019; Craig et al. 2008).

Second, this study adds to the financing literature by advancing on the antecedents and implications of obtaining external funds. More specifically, this study presents a more detailed explanation of how access to financial resources also depends on intangible factors, such as the image of the business. In our approach, the idea of projected image uncovers how family firm decision-makers understand access to financial resources based on a self-assessment criterion. By doing this, this research contributes to the existing family business branding literature by measuring perceived (rather than successful or failed) access to financial resources so as including firms that would otherwise be excluded (e.g., discouraged borrowers). Moreover, this subjective measure enables a more comprehensive understanding of family firm behavior regarding its access to financial resources than would be the case with purely objective data (McCarthy et al. 2017). 


\subsection{Managerial implications}

Our insights on the importance of a projected family firm image as a driver of access to financial resources have some important implications for management practice. Obtaining access to credit and loans is an important challenge for family SMEs, and our study indicates that these firms can succeed in these endeavors if they utilize their family firm image as a marketing tool. Rather than simply considering themselves as family firms, our study encourages family SME owners and managers to invest in reinforcing their projected family firm image as a versatile competitive advantage, since it is considered a credible signal of trustworthiness and prestige. More specifically, reinforcing this image can help reduce information asymmetries between family SME managers and lenders, especially when the latter are not aware of the characteristics or behavioral intentions of the family SME. Furthermore, family firm practitioners are cautioned that reducing this information asymmetry is easier for larger family SMEs, as their projected family firm image evokes a history of success, sustainability, and growth.

\subsection{Limitations and future research opportunities}

Despite the theoretical contributions and managerial implications described above, our study is subject to several limitations that also offer avenues for future research. First, drawing on a sample of SMEs from a single country (Spain) has its limitations. Access to financial resources is closely linked to country-level economic contingencies (Crespí and Martín-Oliver 2015). Thus, future studies should replicate this study in other economic settings. In addition, it would be interesting to focus not only on family SMEs but also on family firms in general to analyze whether these insights apply to larger family owned businesses. Second, our study was cross-sectional in nature. Further evidence on the causal relationships between the dependent and independent variables based on longitudinal research is needed. Our hypotheses are based on existing theory, and our test for common method bias (Podsakoff and Organ 1986) did not reveal any concerns that might have affected our results. However, future research could help explain potential changes in the access to financial resources over time, by collecting longitudinal data. Third, we included a potential firm-level moderating effect only in the conceptual model and empirical analyses. Other variables may moderate the family firm image-access to financial resources relationship. An interesting avenue for future research is to examine the potential moderating effect of CEO characteristics. Finally, we encourage further research on the broader notion of reputation management in the context of family firms, as there is limited empirical evidence on the gaps between image, identity, reputation, and corporate branding strategies. It would also be instructive to explore non-financial factors related to image, such as family firm identity and reputation. 


\section{Conclusion}

Although a projected family firm image has been regarded as an important signal that can potentially influence consumers' (Zanon et al. 2019) and employees' perception (Kahlert et al. 2017), empirical evidence on whether projected family firm image impact in other fields is still lacking (Santiago et al. 2019). Based on a sample of 289 Spanish family SMEs, this study builds on signaling theory to examine whether, from the family SME leaders' perspective, the projected family firm image influences access to financial resources, which is one of the main challenges that these businesses face (European Commission 2015a). Specifically, this study shows that a projected family firm image can act as a positive signal to facilitate access to financial resources, being this effect stronger for larger than for smaller family SMEs. Likewise, it was found that firm age does not affect the positive effect that projected family firm image has on access to financial resources in family SMEs. These insights address a relevant managerial implication in terms of family firm stakeholder perceptions, adding contributions to corporate branding, family business and financing literature.

Acknowledgements This work was financially supported by MCIU/AEI/FEDER-UE under the grant number RTI2018-097579-B-100 and by the UPV/EHU under the grant number GIU19/057.

Funding Open Access funding provided thanks to the CRUE-CSIC agreement with Springer Nature. University of the Basque Country (UPV/EHU), Grant No. GIU19-057, and Ministerio de Ciencia, Innovación y Universidades, Gobierno de España, Grant No. RTI2018-097579-B-100.

Open Access This article is licensed under a Creative Commons Attribution 4.0 International License, which permits use, sharing, adaptation, distribution and reproduction in any medium or format, as long as you give appropriate credit to the original author(s) and the source, provide a link to the Creative Commons licence, and indicate if changes were made. The images or other third party material in this article are included in the article's Creative Commons licence, unless indicated otherwise in a credit line to the material. If material is not included in the article's Creative Commons licence and your intended use is not permitted by statutory regulation or exceeds the permitted use, you will need to obtain permission directly from the copyright holder. To view a copy of this licence, visit http://creativecommons.org/licen ses/by/4.0/.

\section{References}

Aaker DA (2004) Leveraging the corporate brand. Calif Manag Rev 46(3):6-18. https://doi.org/10. $1177 / 000812560404600301$

Abratt R, Kleyn N (2012) Corporate identity, corporate branding and corporate reputations: reconciliation and integration. Eur J Marketing 46(7/8):1048-1063. https://doi.org/10.1108/0309056121 1230197

Alayo M, Maseda A, Iturralde T, Arzubiaga U (2019) Internationalization and entrepreneurial orientation of family SMEs: the influence of the family character. Int Bus Rev 28(1):48-59. https:// doi.org/10.1016/j.ibusrev.2018.06.003

Anker TB, Sparks L, Moutinho L, Grönroos C (2015) Consumer dominant value creation: A theoretical response to the recent call for a consumer dominant logic for marketing. Eur $\mathrm{J}$ Marketing 49(3/4):532-560. https://doi.org/10.1108/EJM-09-2013-0518 
Arijs D, Botero IC, Michiels A, Molly V (2018) Family business employer brand: Understanding applicants' perceptions and their job pursuit intentions with samples from the US and Belgium. J Fam Bus Strategy 9(3):180-191. https://doi.org/10.1016/j.jfbs.2018.08.005

Armstrong JS, Overton TS (1977) Estimating nonresponse bias in mail surveys. J Marketing Res 14(3):396-402. https://doi.org/10.1177/002224377701400320

Arosa B, Iturralde T, Maseda A (2010) Ownership structure and firm performance in non-listed firms: evidence from Spain. J Fam Bus Strategy 1(2):88-96. https://doi.org/10.1016/j.jfbs.2010.03.001

Arzubiaga U, Kotlar J, De Massis A, Maseda A, Iturralde T (2018) Entrepreneurial orientation and innovation in family SMEs: Unveiling the (actual) impact of the Board of Directors. J Bus Ventur 33(4):455-469. https://doi.org/10.1016/j.jbusvent.2018.03.002

Azim MI (2012) Corporate governance mechanisms and their impact on company performance: a structural equation model analysis. Aust J Manag 37(3):481-505. https://doi.org/10.1177/03128 96212451032

Baek TH, Kim J, Yu JH (2010) The differential roles of brand credibility and brand prestige in consumer brand choice. Psychol Market 27(7):662-678. https://doi.org/10.1002/mar.20350

Balmer JM, Gray ER (2003) Corporate brands: what are they? What of them? Eur J Marketing 37(7/8):972-997. https://doi.org/10.1108/03090560310477627

Beck S, Kenning P (2015) The influence of retailers' family firm image on new product acceptance. Int J Ret Distrib Manag 43(12):1126-1143. https://doi.org/10.1108/JJRDM-06-2014-0079

Beck S, Prügl R (2018) Family firm reputation and humanization: consumers and the trust advantage of family firms under different conditions of brand familiarity. Fam Bus Rev 31(4):460-482. https://doi.org/10.1177/0894486518792692

Beck S, Prügl R, Walter K (2020) Communicating the family firm brand: antecedents and performance effects. Eur Manag J 38(1):95-107. https://doi.org/10.1016/j.emj.2019.04.008

Berghman L, Matthyssens P, Streukens S, Vandenbempt K (2013) Deliberate learning mechanisms for stimulating strategic innovation capacity. Long Range Plann 46(1):39-71. https://doi.org/10. 1016/j.1rp.2012.11.003

Besharat A (2010) How co-branding versus brand extensions drive consumers' evaluations of new products: a brand equity approach. Ind Mark Manag 39(8):1240-1249. https://doi.org/10. 1016/j.indmarman.2010.02.021

Bichler BF, Kallmuenzer A, Peters M, Petry T, Clauss T (2021) Regional entrepreneurial ecosystems: how family firm embeddedness triggers ecosystem development. Rev Manag Sci. https://doi. org/10.1007/s11846-020-00434-9

Binz-Astrachan C, Hair JF, Pieper TM, Baldauf A (2013) Exploring the effect of distinct family firm reputation on consumers' preferences. J Fam Bus Strategy 4(1):3-11. https://doi.org/10.1016/j. jfbs.2012.12.004

Binz-Astrachan C, Patel VK, Wanzenried G (2014) A comparative study of CB-SEM and PLS-SEM for theory development in family firm research. J Fam Bus Strategy 5(1):116-128. https://doi. org/10.1016/j.jfbs.2013.12.002

Binz-Astrachan C, Botero I, Astrachan JH, Prügl R (2018) Branding the family firm: a review, integrative framework proposal, and research agenda. J Fam Bus Strategy 9(1):3-15. https://doi.org/10. 1016/j.jfbs.2018.01.002

Blanco-Mazagatos V, de Quevedo-Puente E, Castrillo LA (2007) The trade-off between financial resources and agency costs in the family business: an exploratory study. Fam Bus Rev 20(3):199-213. https://doi.org/10.1111/j.1741-6248.2007.00095.x

Blombäck A (2011) Realizing the value of family business identity as corporate brand elementa research model. http://www.diva-portal.org/smash/get/diva2:462728/FULLTEXT01.pdf. Accessed 23 March 2019

Botero IC (2014) Effects of communicating family ownership and organisational size on an applicant's attraction to a firm: An empirical examination in the USA and China. J Fam Bus Strategy 5(2):184-196. https://doi.org/10.1016/j.jfbs.2014.01.004

Botero IC, Thomas J, Graves C, Fediuk TA (2013) Understanding multiple family firm identities: an exploration of the communicated identity in official websites. J Fam Bus Strategy 4(1):12-21. https://doi.org/10.1016/j.jfbs.2012.11.004

Botero IC, Binz-Astrachan C, Calabrò A (2018) A receiver's approach to family business brands. J Fam Bus Manag 8(1):2-21. https://doi.org/10.1108/JFBM-03-2017-0010 
Brinkerink J, Rondi E, Benedetti C, Arzubiaga U (2020) Family business or business family? Organizational identity elasticity and strategic responses to disruptive innovation. J Fam Bus Strategy 11(4):100360. https://doi.org/10.1016/j.jfbs.2020.100360

Brown TJ, Dacin PA, Pratt MG, Whetten DA (2006) Identity, intended image, construed image, and reputation: an interdisciplinary framework and suggested terminology. J Acad Marketing Sci 34(2):99-106. https://doi.org/10.1177/0092070305284969

Camara da NZ (2011) Identity, image and reputation. In: Helm S, Liehr-Gobbers K, Storck C (Eds.), Reputation management (pp 47-58). Springer, Berlin, Heidelberg

Campbell DT, Fiske DW (1959) Convergent and discriminant validation by the multitrait-multimethod matrix. Psychol Bull 56(2):81-105. https://doi.org/10.1037/h0046016

Carrigan M, Buckley J (2008) What's so special about family business? An exploratory study of UK and Irish consumer experiences of family businesses. Int J of Consum Stud 32(6):656-666. https://doi. org/10.1111/j.1470-6431.2008.00696.x

Casado-Belmonte Md, Capobianco-Uriarte Md, Martínez-Alonso R, Martínez-Romero MJ (2021) Delineating the path of family firm innovation: mapping the scientific structure. Rev Manag Sci 15:2455-2499. https://doi.org/10.1007/s11846-021-00442-3

Casillas JC, López MC, Meroño A, Pons A, Baiges R (2016) La empresa familiar en España. Instituto de Empresa Familiar. https://catedraempresafamiliar.uca.es/wp-content/uploads/2018/02/La_empre sa_familiar_en_Espana_2015.pdf?u. Accessed 28 September 2019

Chandler JA, Payne GT, Moore C, Brigham KH (2019) Family involvement signals in initial public offerings. J Fam Bus Strategy 10(1):8-16. https://doi.org/10.1016/j.jfbs.2019.01.004

Chaudhuri A, Holbrook MB (2001) The chain of effects from brand trust and brand affect to brand performance: the role of brand loyalty. J Marketing 65(2):81-93. https://doi.org/10.1509/jmkg.65.2. 81.18255

Chin WW (1998) The partial least squares approach to structural equation modeling. Mod Met Bus Res 295(2):295-336

Chua JH, Chrisman JJ, Kellermanns F, Wue Z (2009) Family involvement and new venture debt financing. J Bus Ventur 26(4):1-17. https://doi.org/10.1016/j.jbusvent.2009.11.002

Connelly BL, Certo ST, Ireland RD, Reutzel CR (2011) Signaling theory: a review and assessment. J Manag 37(1):39-67. https://doi.org/10.1177/0149206310388419

Cooper MJ, Upton N, Seaman S (2005) Customer relationship management: a comparative analysis of family and nonfamily business practices. J Small Bus Manag 43(3):242-256. https://doi.org/10. 1111/j.1540-627X.2005.00136.X

Covin JG, Eggers F, Kraus S, Cheng CF, Chang ML (2016) Marketing-related resources and radical innovativeness in family and non-family firms: a configurational approach. J Bus Res 69(12):56205627. https://doi.org/10.1016/j.jbusres.2016.03.069

Craig JB, Dibrell C, Davis PS (2008) Leveraging family-based brand identity to enhance firm competitiveness and performance in family businesses. J Small Bus Manag 46(3):351-371. https://doi.org/ 10.1111/j.1540-627X.2008.00248.x

Crespí R, Martín-Oliver A (2015) Do family firms have better access to external finance during crises? Corp Gov 23(3):249-265. https://doi.org/10.1111/corg.12100

Cruz C, Justo R, Roche J (2021) Engaging in a new field: business-owning families' differential approach to impact investing. Eur J Fam Bus 11(1):21-32. https://doi.org/10.24310/ejfbejfb.v11i1.12626

Dawes J (2008) Do data characteristics change according to the number of scale points used? An experiment using 5-point, 7-point and 10-point scales. Int J Mark Res 50(1):61-104

Deephouse DL, Jaskiewicz P (2013) Do family firms have better reputations than non-family firms? An integration of socioemotional wealth and social identity theories. J Manag Stud 50(3):337-360. https://doi.org/10.1111/joms.12015

Donaldson T, Preston LE (1995) The stakeholder theory of the corporation: concepts, evidence, and implications. Acad Manag Rev 20(1):65-91. https://doi.org/10.5465/amr.1995.9503271992

Dyer WG (2003) The family: the missing variable in organizational research. Entrepr Theory Pract 27(4):401-416. https://doi.org/10.1111/1540-8520.00018

Dyer WG Jr, Whetten DA (2006) Family firms and social responsibility: preliminary evidence from the S\&P 500. Entrepr Theory Pract 30(6):785-802. https://doi.org/10.1111/j.1540-6520.2006.00151.x

Eggers F, O'Dwyer M, Kraus S, Vallaster C, Güldenberg S (2013) The impact of brand authenticity on brand trust and SME growth: a CEO perspective. J World Bus 48(3):340-348. https://doi.org/10. 1016/j.jwb.2012.07.018 
Elbanna S, Child J, Dayan M (2013) A model of antecedents and consequences of intuition in strategic decision-making: evidence from Egypt. Long Range PlAnn 46(1):149-176. https://doi.org/10. 1016/j.lrp.2012.09.007

Erdem T, Swait J (2004) Brand credibility, brand consideration, and choice. J Consum Res 31(1):191198. https://doi.org/10.1086/383434

European Commission (2015a) Overview of family business relevant issues. http://www.europeanfa milybusinesses.eu/uploads/Modules/Publications/overview-of-family-business-relevant-issues.pdf. Accessed 28 Sep 2019

European Commission (2015b) European-Semester Thematic factsheet. Small-medium-sized enterprises access to finance. https://ec.europa.eu/info/sites/default/files/file_import/european-semester_thema ticfactsheet_small-medium-enterprises-access-finance_en.pdf (europa.eu). Accessed 28 Sep 2019

Fabrizio CM, Kaczam F, de Moura GL et al (2021) Competitive advantage and dynamic capability in small and medium-sized enterprises: a systematic literature review and future research directions. Rev Manag Sci. https://doi.org/10.1007/s11846-021-00459-8

Falk RF, Miller NB (1992) A primer for soft modeling. University of Akron Press

Fernández-Olmos M, Gargallo-Castel A, Giner-Bagües E (2016) Internationalisation and performance in Spanish family SMES: the W-curve. BRQ Bus Res Q 19(2):122-136. https://doi.org/10.1016/j.brq. 2015.07.001

Foreman PO, Whetten DA, Mackey A (2012) An identity-based view of reputation, image, and legitimacy: clarifications and distinctions among related constructs. In: Pollock TG, Barnett ML (Eds.), The Oxford handbook of corporate reputation. Oxford University Press

Garcés-Ayerbe C, Rivera-Torres P, Murillo-Luna JL et al (2021) Does it pay more to be green in family firms than in non-family firms? Rev Manag Sci. https://doi.org/10.1007/s11846-021-00475-8

Gefen D, Straub D, Boudreau MC (2000) Structural equation modeling and regression: guidelines for research practice. Commun Assoc Inf Syst 4(7): 1-77. https://doi.org/10.17705/1CAIS.00407.

George G (2005) Slack resources and the performance of privately held firms. Acad Manag J 48(4):661676. https://doi.org/10.5465/amj.2005.17843944

Gotsi M, Wilson AM (2001) Corporate reputation: seeking a definition. Corp Comm Int J 6(1):24-30. https://doi.org/10.1108/13563280110381189

Grewal R, Chakravarty A, Saini A (2010) Governance mechanisms in business-to-business electronic markets. J Marketing 74(4):45-62. https://doi.org/10.1509/jmkg.74.4.045

Groote de JK, Conrad W, Hack A (2021) How can family businesses survive disruptive industry changes? Insights from the traditional mail order industry. Rev Manag Sci. https://doi.org/10.1007/ s11846-020-00424-X

Gruber M, Heinemann F, Brettel M, Hungeling S (2010) Configurations of resources and capabilities and their performance implications: an exploratory study on technology ventures. Strateg Manag J 31(12):1337-1356. https://doi.org/10.1002/smj.865

Hair JF, Sarstedt M, Ringle CM, Mena JA (2012) An assessment of the use of partial least squares structural equation modeling in marketing research. J Acad Market Sci 40(3):414-433. https://doi.org/ 10.1007/s11747-011-0261-6

Harman HH (1967) Modem factor analysis. University of Chicago, Chicago

Hatch MJ, Schultz M (2003) Bringing the corporation into corporate branding. Eur J Marketing 37(7/8):1041-1064. https://doi.org/10.1108/03090560310477654

Hauswald H, Hack A, Kellermanns FW, Patzelt H (2016) Attracting new talent to family firms: Who is attracted and under what conditions? Entrepr Theory Pract 40(5):963-989. https://doi.org/10.1111/ etap. 12153

Hulland J (1999) Use of partial least squares (PLS) in strategic management research: a review of four recent studies. Strategic Manag J 20(2):195-204. https://doi.org/10.1002/(SICI)10970266(199902)20:2\%3c195::AID-SMJ13\%3e3.0.CO;2-7

Kahlert C, Botero IC, Prügl R (2017) Revealing the family. J Fam Bus Manag 7(1):21-43. https://doi.org/ 10.1108/JFBM-10-2015-0037

Kallmuenzer A, Peters M, Buhalis D (2020) The role of family firm image perception in host-guest value co-creation of hospitality firms. Curr Issues Tour 23(19):2410-2427. https://doi.org/10.1080/ 13683500.2019.1611746

Kärreman D, Rylander A (2008) Managing meaning through branding: the case of a consulting firm. Organ Stud 29(1):103-125. https://doi.org/10.1177/0170840607084573

Kashmiri S, Mahajan V (2010) What's in a name? An analysis of the strategic behavior of family firms. Int J Res Mark 27(3):271-280. https://doi.org/10.1016/j.ijresmar.2010.04.001 
Kastanakis MN, Balabanis G (2012) Between the mass and the class: antecedents of the "bandwagon" luxury consumption behavior. J Bus Res 65(10):1399-1407. https://doi.org/10.1016/j.jbusres.2011. 10.005

Kerr WR, Nanda R (2015) Financing innovation. Annu Rev Financ Econ 7:445-462. https://doi.org/10. 1146/annurev-financial-111914-041825

Knox S, Bickerton D (2003) The six conventions of corporate branding. Eur J Marketing 37(7/8):9981016. https://doi.org/10.1108/03090560310477636

Kortmann S (2015) The mediating role of strategic orientations on the relationship between ambidexterity-oriented decisions and innovative ambidexterity. J Prod Innovat Manag 32(5):666-684. https:// doi.org/10.1111/jpim.12151

Krappe A, Goutas L, von Schlippe A (2011) The "family business brand": an enquiry into the construction of the image of family businesses. J Fam Bus Manag 1(1):37-46. https://doi.org/10.1108/ 20436231111122272

Landau C, Bock C (2013) Value creation through vertical intervention of corporate centres in single business units of unrelated diversified portfolios: the case of private equity firms. Long Range Plann 46(1):97-124. https://doi.org/10.1016/j.lrp.2012.11.002

LaPlaca PJ (2010) Special issue on building, implementing, and managing brand equity in business markets. Ind Mark Manag 8(39):1219-1222. https://doi.org/10.1016/j.indmarman.2010.10.001

Lee N, Sameen H, Cowling M (2015) Access to finance for innovative SMEs since the financial crisis. Res Policy 44(2):370-380. https://doi.org/10.1016/j.respol.2014.09.008

López-Delgado P, Diéguez-Soto J (2020) Indebtedness in family-managed firms: the moderating role of female directors on the board. Rev Manag Sci 14:727-762. https://doi.org/10.1007/ s11846-018-0307-y

Lu JW, Beamish PW (2001) The internationalization and performance of SMEs. Strateg Manag J 22(67):565-586. https://doi.org/10.1002/smj.184

Lude M, Prügl R (2018) Why the family business brand matters: Brand authenticity and the family firm trust inference. J Bus Res 89:121-134. https://doi.org/10.1016/j.jbusres.2018.03.040

Mai R, Niemand T, Kraus S (2021) A tailored-fit model evaluation strategy for better decisions about structural equation models. Technol Forecast Soc Chang 173:121142. https://doi.org/10.1016/j. techfore.2021.121142

McCarthy S, Oliver B, Verreynne ML (2017) Bank financing and credit rationing of Australian SMEs. Aust J Manag 42(1):58-85. https://doi.org/10.1177/0312896215587316

Memili E, Eddleston KA, Kellermanns FW, Zellweger TM, Barnett T (2010) The critical path to family firm success through entrepreneurial risk taking and image. J Fam Bus Strategy 1(4):200-209. https://doi.org/10.1016/j.jfbs.2010.10.005

Micelotta ER, Raynard M (2011) Concealing or revealing the family? Corporate brand identity strategies in family firms. Fam Bus Rev 24(3):197-216. https://doi.org/10.1177/0894486511407321

Michiels A, Molly V (2017) Financing decisions in family businesses: a review and suggestions for developing the field. Fam Bus Rev 30(4):369-399. https://doi.org/10.1177/0894486517736958

Michiels A, Arijs D, Uhlaner L (2021) Formal HRM in family SMEs: the role of family-centered goals and family governance. Rev Manag Sci. https://doi.org/10.1007/s11846-021-00509-1

Miller D, Le Breton-Miller I (2006) Family governance and firm performance: agency, stewardship, and capabilities. Fam Bus Rev 19(1):73-87. https://doi.org/10.1111/j.1741-6248.2006.00063.x

Molly V, Laveren E, Jorissen A (2012) Intergenerational differences in family firms: impact on capital structure and growth behavior. Entrepr Theory Pract 36(4):703-725. https://doi.org/10.1111/j. 1540-6520.2010.00429.x

Nag R, Corley KG, Gioia DA (2007) The intersection of organizational identity, knowledge, and practice: attempting strategic change via knowledge grafting. Acad Manag J 50(4):821-847. https://doi.org/ 10.5465/amj.2007.26279173

Neckebrouck J, Meuleman M, Manigart S (2021) Governance implications of attracting external equity investors in private family firms. Acad Manag Perspect 35(1):25-44. https://doi.org/10.5465/amp. 2017.0204

Oliveira B, Fortunato A (2006) Firm growth and liquidity constraints: a dynamic analysis. Small Bus Econ 27(2-3):139-156. https://doi.org/10.1007/s11187-006-0006-y

Orth UR, Green MT (2009) Consumer loyalty to family versus non-family business: the roles of store image, trust and satisfaction. J Retail Consum Serv 16(4):248-259. https://doi.org/10.1016/j.jretc onser.2008.12.002 
Pappu R, Quester PG (2016) How does brand innovativeness affect brand loyalty? Eur J Marketing 50(1/2):2-28. https://doi.org/10.1108/EJM-01-2014-0020

Podsakoff PM, Organ DW (1986) Self-reports in organizational research: problems and prospects. J Manag 12(4):531-544. https://doi.org/10.1177/014920638601200408

Podsakoff PM, MacKenzie SB, Lee JY, Podsakoff NP (2003) Common method biases in behavioral research: a critical review of the literature and recommended remedies. J Appl Psychol 88(5):879891. https://doi.org/10.1037/0021-9010.88.5.879

Ringle CM, Wende S, Will A (2005) SmartPLS 2.0. University of Hamburg. Hamburg, Germany. Available at www.smartpls.de

Robeson D, O'Connor GC (2013) Boards of directors, innovation, and performance: an exploration at multiple levels. J Prod Innovat Manag 30(4):608-625. https://doi.org/10.1111/jpim.12018

Roffia P, Moracchiato S, Liguori E, Kraus S (2021) Operationally defining family SMEs: a critical review. J Small Bus Enterp Dev 28(2):229-260. https://doi.org/10.1108/JSBED-11-2020-0399

Romano CA, Tanewski GA, Smyrnios KX (2001) Capital structure decision making: a model for family business. J Bus Ventur 16(3):285-310. https://doi.org/10.1016/S0883-9026(99)00053-1

Rovelli P, Ferasso M, De Massis A, Kraus S (2021) Thirty years of research in family business journals: status quo and future directions. J Fam Bus Strategy. https://doi.org/10.1016/j.jfbs.2021.100422

Sageder M, Mitter C, Feldbauer-Durstmüller B (2018) Image and reputation of family firms: a systematic literature review of the state of research. Rev Manag Sci 12(1):335-377. https://doi.org/10.1007/ s11846-016-0216-X

Santiago A, Pandey S, Manalac MT (2019) Family presence, family firm reputation and perceived financial performance: empirical evidence from the Philippines. J Fam Bus Strategy 10(1):49-56. https://doi.org/10.1016/j.jfbs.2019.02.002

Schellong M, Kraiczy ND, Malär L, Hack A (2019) Family firm brands, perceptions of doing good, and consumer happiness. Entrepr Theory Pract 43(5):921-946. https://doi.org/10.1177/1042258717 754202

Schneider C, Veugelers R (2010) On young highly innovative companies: why they matter and how (not) to policy support them. Ind Corp Chang 19(4):969-1007. https://doi.org/10.1093/icc/dtp052

Schuster T, Holtbrügge D (2014) Resource dependency, innovative strategies, and firm performance in BOP Markets. J Prod Innovat Manag 31(1):43-59. https://doi.org/10.1111/jpim.12191

Sirmon DG, Hitt MA (2003) Managing resources: Linking unique resources, management, and wealth creation in family firms. Entrepr Theory Pract 27(4):339-358. https://doi.org/10.1111/1540-8520. t01-1-00013

Spence M (1973) Job market signaling. Q J Econ 87(3):355-374

Spence M (2002) Signaling in retrospect and the informational structure of markets. Am Econ Rev 92(3):434-459. https://doi.org/10.1257/00028280260136200

Steijvers T, Voordeckers W (2009) Private family ownership and the agency costs of debt. Fam Bus Rev 22(4):333-346. https://doi.org/10.1177/0894486509338291

Stiglitz JE (2000) The contributions of the economics of information to twentieth century economics. Q J Econ 115(4):1441-1478. https://doi.org/10.1162/003355300555015

Strobl A, Matzler K, Nketia BA, Veider V (2020) Individual innovation behavior and firm-level exploration and exploitation: how family firms make the most of their managers. Rev Manag Sci 14(4):809-844. https://doi.org/10.1007/s11846-018-0309-9

Sundaramurthy C, Kreiner GE (2008) Governing by managing identity boundaries: the case of family businesses. Entrepr Theory Pract 32(3):415-436. https://doi.org/10.1111/j.1540-6520.2008. 00234.x

Taj SA (2016) Application of signaling theory in management research: addressing major gaps in theory. Eur Manag J 34(4):338-348

Tenenhaus M, Vinzi VE, Chatelin YM, Lauro C (2005) PLS path modeling. Comput Stat Data Anal 48(1):159-205. https://doi.org/10.1016/j.csda.2004.03.005

Thai MTT, Turkina E (2014) Macro-level determinants of formal entrepreneurship versus informal entrepreneurship. J Bus Ventur 29(4):490-510. https://doi.org/10.1016/j.jbusvent.2013.07.005

Van Gils A, Huybrechts J, Minola T, Cassia L (2019) Unraveling the impact of family antecedents on family firm image: a serial multiple-mediation model. J Fam Bus Strategy 10(1):17-27. https://doi. org/10.1016/j.jfbs.2019.02.001

Voordeckers W, Van Gils A, Van den Heuvel J (2007) Board composition in small and medium-sized family firms. J Small Bus Manag 45(1):137-156. https://doi.org/10.1111/j.1540-627X.2007. 00204.x 
Vos E, Yeh AJY, Carter S, Tagg S (2007) The happy story of small business financing. J Bank Finance 31(9):2648-2672. https://doi.org/10.1016/j.jbankfin.2006.09.011

Westhead P, Cowling M (1998) Family firm research: the need for a methodological rethink. Entrepr Theory Pract 23(1):31-56. https://doi.org/10.1177/104225879802300102

Wiklund J, Shepherd D (2005) Entrepreneurial orientation and small business performance: a configurational approach. J Bus Ventur 20(1):71-91. https://doi.org/10.1016/j.jbusvent.2004.01.001

Zanon J, Scholl-Grissemann U, Kallmuenzer A, Kleinhansl N, Peters M (2019) How promoting a family firm image affects customer perception in the age of social media. J Fam Bus Strategy 10(1):2837. https://doi.org/10.1016/j.jfbs.2019.01.007

Zellweger T (2007) Time horizon, costs of equity capital, and generic investment strategies of firms. Fam Bus Rev 20(1):1-15. https://doi.org/10.1111/j.1741-6248.2007.00080.x

Zellweger TM, Kellermanns FW, Chrisman JJ, Chua JH (2012) Family control and family firm valuation by family CEOs: the importance of intentions for transgenerational control. Organ Sci 23(3):851868. https://doi.org/10.1287/orsc. 1110.0665

Publisher's Note Springer Nature remains neutral with regard to jurisdictional claims in published maps and institutional affiliations.

\section{Authors and Affiliations}

\section{Unai Arzubiaga $^{1}$ (D) Alfredo De Massis ${ }^{2,3,4,5} \cdot$ Amaia Maseda $^{1} \cdot$ Txomin Iturralde $^{6}$}

Alfredo De Massis

Alfredo.DeMassis@unibz.it

Amaia Maseda

amaia.maseda@ehu.eus

Txomin Iturralde

txomin.iturralde@ehu.eus

1 Department of Financial Economics I, University of the Basque Country (UPV/EHU), Bilbao, Spain

2 Centre for Family Business Management, Free University of Bozen-Bolzano, Bozen-Bolzano, Italy

3 Department of Entrepreneurship and Strategy, Lancaster University Management School (UK), Lancaster, UK

4 Institute of Family Business and Institute for Entrepreneurs, Zhejiang University, Hangzhou, China

5 IMD Business School, Lausanne, Switzerland

6 Department of Financial Economics II, University of the Basque Country (UPV/EHU), Bilbao, Spain 